\section{Weight and height of people living with HIV/AIDS attended by the Brazilian National Health System}

\section{Peso e altura de pessoas vivendo com HIV/aids em atendimento no Sistema Único de Saúde}

Katia Cristina Bassichetto'

Denise Pimentel Bergamaschi"

Deivis Elton Schlickmann Frainer"II

Vania Regina Salles Garcia'

Edina Aparecida Tramarin Trovões'

'São Paulo Municipal Health Secretariat - São Paulo (SP), Brazil.

"Departmento of Epidemiology, School of Public Health,Universidade de São Paulo São Paulo (SP), Brazil.

"'Institute of Collective Health, Universidade Federal da Bahia - Salvador (BA), Brazil.

\section{Abstract}

The nutritional status of people living with HIV/AIDS (PLWHA) is related to morbidity and mortality and its monitoring is important in the maintenance of the health status. This is a cross-sectional study carried out in Brazilian National Health System in the Municipality of São Paulo. It describes anthropometrical characteristics: weight and height; indices of weight for height (W/H), heightfor age (H/A), bodymassindex for age (BMI/A) and $\mathrm{Z}$ score for height and weight. The study includes 772 participants from all ages: children, adolescents, adults and elderly. The graphical analysis shows that in under-5s and in the 5 to 19 years old group, the $\mathrm{W} / \mathrm{H}$, the $\mathrm{H} / \mathrm{A}$ and the $\mathrm{BMI} / \mathrm{A}$ curves are similar to the reference population with an exception in the H/A for 5 to 19 years old group which is left-shifted (mean $\mathrm{Z}=-0.66$ ). In the case of adults, graphics for the study population show median weight apparently lower than in the reference population for most age groups in the case of men, and when age is greater in women. The proportion of people over 20 years old with AIDS on anti-retroviral therapy is lower when coinfection is present $(\mathrm{p}<0.001)$. The findings of the study showed that, for children and adolescents with HIV/AIDS, the average weight and height are lower than the values for non infected population. For adults and elderly, the weight average is lower than the reference population with a worsening among coinfected patients. This underscores the need to direct more effort in nutritional actions thus helping enhance the health status of this group.

Keywords: Body weight. Body height. HIV. Research in health services. Public health. Epidemiology.

Corresponding author: Katia Cristina Bassichetto. Rua General Jardim, 36, 5 andar, Vila Buarque, CEP: 01223-010, São Paulo, SP, Brazil. E-mail: kcbassi@gmail.com

Conflict of interests: nothing to declare. 


\section{Resumo}

$\mathrm{O}$ estado nutricional de pessoas que vivem com HIV/aids (PVHA) está relacionado a morbidade e mortalidade e seu monitoramento auxilia na manutenção do estado de saúde. Este é um estudo de corte transversal realizado no Sistema Único de Saúde no Município de São Paulo. O presente estudo descreve características antropométricas: peso e altura; índices de peso para estatura $(\mathrm{P} / \mathrm{E})$, estatura para idade (E/I), índice de massa corporal para idade (IMC/I) e escore $\mathrm{Z}$ para peso e estatura. Inclui 772 participantes entre crianças, adolescentes, adultos e idosos. A análise gráfica mostra que, em crianças menores de 5 anos e no grupo de 5 a 19 anos, o P/E, a E/I e as curvas de IMC/I são semelhantes às da população de referência, com uma exceção onde a curva de E/I para o grupo de 5 a 19 anos é deslocada para a esquerda (média $\mathrm{Z}=-0,66$ ). No caso dos adultos, observou-se mediana de peso aparentemente menor do que a população de referência para a maioria dos grupos de idade entre os homens e para as mulheres em idade mais avançada. A proporção de pessoas maiores de 20 anos com aids usando terapia antirretroviral é menor na presença de coinfecção ( $\mathrm{p}<0,001)$. As conclusões do estudo mostraram que crianças e adolescentes com HIV/aids apresentam estatura e peso médio inferior à população não infectada. Entre os adultos e idosos, o peso médio é menor que o da população de referência, principalmente na presença de coinfecção. Enfatiza-se a necessidade de reforçar ações nutricionais, contribuindo, assim, para melhoria do estado de saúde desse grupo.

Palavras-chave: Peso corporal. Estatura. HIV. Pesquisa nos serviços de saúde. Saúde pública. Epidemiologia.

\section{Introduction}

From 1980 to 2008, 71,508 cases of AIDS were notified in the city of São Paulo: 69,274 (96.9\%) adults, 2,126 (3\%) children and 108 cases in which age was unknown, accounting for $15.7 \%$ of cases in Brazil in the same period ${ }^{1,2}$. Given the association between nutritional status and health ${ }^{3}$, people living with HIV/ aids (PLWHA) may undergo nutritional and metabolic changes depending on how long ago they were diagnosed with HIV/AIDS, on the presence of coinfection, and on the length of time and drug therapy combination they had been ${ }^{4-6}$. In caring for PLWHA, nutritional status must be taken into consideration, either in order to avoid involuntary weight loss, wasting, fever, and diarrhea or due to side effects of antiretroviral therapy (ARVT) use $^{4-11}$. Nutritional disorders may also predict the course of HIV infection, and the management of these disorders may help in the recovery or maintenance of health status ${ }^{4,11-13}$. The assessment of weight and height is part of the evaluation of nutritional status and has been widely used in epidemiological studies because it is easy to carry out, affordable and non-invasive ${ }^{3}$. The goal of this study was to assess for any age groups weight and for children and adolescents, height as nutritional indicators as well as the infection time (IT), time of follow-up in the units (TF) and ARVT use of PLWHA which are followed up in the sexually transmitted disease (STD)/ AIDS municipal clinics.

\section{Population and methods}

\section{Type of study and selection of participants}

This is a cross-sectional study carried out from January 2008 to September 2009, with sampling of users of 12 out of 15 care clinics of São Paulo Municipal STD/AIDS Program, where patients receive multidisciplinary assistance, including nutritional care. The subjects and the minor's parents or guardians were invited to take part in the study during their routine visits to the clinics.

The sample size was calculated based on a proportion of $50 \%$ of undernourished 
individuals, $1.5 \%$ accuracy and 95\% degree of confidence, adding $20 \%$ of losses. The sample was intended to represent PLWHA attended during the year 2008 in the Brazilian National Health System (SUS), resulting in 772 subjects.

The coinfections considered were: Tuberculosis, Hepatitis B or C or Tuberculosis + Hepatitis B and/or C. Inclusion criteria were: to be in follow-up at one of the clinics during the period of the study and to have HIV or AIDS. Exclusion criteria were: the presence of hyper- or hypothyroidism, neurological changes, physical disabilities that made it difficult to take anthropometric measurements, to be pregnant, to be unable to walk, and to have silicone prostheses.

The study was approved by the Department of Health Municipality (SMS-SP) Committee for Ethics in Research, and measurements were taken during an appointment with the pediatrician or dietitian, using a specific form, later a free and informed consent agreement was signed; confidentiality was guaranteed.

\section{Clinical and care data}

Infection known time (IT) and time of follow-up (TF) were calculated by the interval between the date of the interview and the first positive serological results for HIV (IT) and the date of the first appointment at the service (TF), respectively, obtained from the medical records. Average times were then calculated, according to age bracket and infection status.

\section{Anthropometric data}

Anthropometrical measurements current weight $(\mathrm{kg})$, length and height $(\mathrm{cm})$ were measured in duplicate by trained professionals, following procedures recommended by Lohman ${ }^{14}$ and World Health Organization $(\mathrm{WHO})^{15}$, using values calculated by the arithmetic average of the two measurements. The following indices were calculated: weight for height $(\mathrm{W} / \mathrm{H})$; height for age (H/A); body mass index for age [(weight $(\mathrm{kg}) /$ height $\left.\left.\left.\left(\mathrm{m}^{2}\right)\right)\right]\right]^{15}$ (BMI/Age). Standard deviations (SD) in relation to a reference median ( $\mathrm{Z}$ score) for the population were calculated for children and adolescents (WHO) $)^{16,17}$, by gender and age, and $\mathrm{W} / \mathrm{H}$ and $\mathrm{H} / \mathrm{A}$ were used in the under-5s, and BMI/Age and H/A for 5 to 18 years old. Comparison between the results obtained and the reference population was carried out by curves constructed using Anthro and Anthro Plus ${ }^{18,19}$.

The following categories for $\mathrm{H} / \mathrm{A}$ were adopted for classifying the nutritional status: very low height for age $(Z<-3)$, low height for age $(-3<Z<-2)$, adequate height for age $(\mathrm{Z} \geq-2)$; for $\mathrm{W} / \mathrm{H}$ : low weight for height $(\mathrm{Z}<-2)$, adequate weight for height $(-2 \leq \mathrm{Z}<+2)$, high weight for height $(Z \geq+2)$. The following were used for BMI/age: low BMI for age $(\mathrm{Z}<-2)$, adequate $B M I$ for age $(-2 \leq Z<+1)$, overweight $(+1 \leq \mathrm{Z}<+2)$ and obesity $(\mathrm{Z} \geq+2)^{16,17}$.

\section{Statistical analysis}

The average values and SD for weight and height were presented for children and adolescents by gender and compared to reference populations according to the age bracket: 2 to 18 years old - National Center for Health Statistics (NCHS) (same age bracket) ${ }^{20}$ and Anjos (4 to 17 years old) ${ }^{21}$.

Some research data were imputed by polynomial equations, for weight and height for boys ( 5 and 16 years old) and girls (4, 16 and 18 years old), owing to the lack of individuals of these ages. In order to compare the BMI/ age for children and adolescents with HIV/ AIDS with the reference population (NCHS) ${ }^{20}$, it was decided to present the observed data on curves adjusted by second-order polynomials in order to minimize the influence of fluctuations and facilitate understanding.

For people 20 years old and over, the median values for weight were presented graphically and compared to the Family Budget Survey, 2008 - 2009 (POF/IBGE São Paulo city) ${ }^{22}$.

Stata Version $11^{\square 23}$ was used: statistical analysis of the data includes summary measures (average, SD), ANOVA and Scheffé test, Pearson's $\chi^{2}$ association test and Yule's association coefficient; p-value was used in statistical decision-making. 


\section{Results}

\section{Study population}

A total of 772 PLWHA (51.4\% females) took part in the study: 71 children ( $<10$ years, $9.2 \%$ ), 71 adolescents (10 to 19 years, $9.2 \%$ ) and 630 adults and elderly people (20 years and over, $81.6 \%$ ). A similar proportion of men to women was observed for all age-brackets $(\mathrm{p}=0.140)$ (data not presented).

The IT (years)-average and SD among children was 5.1 years $(\mathrm{SD}=2.9)$; among adolescents, 7.6 years $(\mathrm{SD}=4.3)$ and among adults and elderly, 5.2 years (SD = 4.6). For TF, the observed average years and SD were: among children, 4.6 years $(\mathrm{SD}=3.0)$; among adolescents, 6.9 years $(\mathrm{SD}=4.2)$ and among adults and elderly, 4.1 years $(\mathrm{SD}=3.7)$. Proportion of ARVT use was over $93 \%$ among children, adolescents to 14 years of age and elderly patients with AIDS, and $80 \%$ among 15 to 19 years old adolescents, and $87.2 \%$ for adults and elderly with AIDS. For this group, 38.4\% presented coinfection. An association was identified between the variables "use of ARVT" and "coinfection", with statistically higher proportions of not using ARVT among people with coinfection $(13 / 269=26 \%$ versus $43 / 168$ $=5 \%)(\mathrm{p}<0.001)($ data not presented $)$.

\section{Anthropometrical characteristics}

\section{Children and adolescents}

For under-5 children with HIV/AIDS, the $\mathrm{W} / \mathrm{H}$ curve observed in this study was rightshifted with mean of 0.43 and SD equals to 1.02 in comparison with the reference population (Fig. 1 and 2). The proportion of children in this group of age classified in the category high weight for height for both genders was 5.9\% (95\% CI 0.0 - 20.0) (data not presented).

Also for children under- 5 with HIV/AIDS, the H/A curve, for both genders, showed a left-shifted pattern (mean: $-0.31 ; 1.3 \mathrm{SD}$ ) (Figs. 1 and 2), where $5.9 \%(95 \%$ CI $0.0-20.0)$ of this age group children presented low height for age (data not presented).

For 5-to-19 years old, the H/A curve was left-shifted (mean: -0.66; 1.16 SD) compared with the reference population, corresponding to $2.5 \%$ (95\%CI 0.0 - 5.8) with very low height for age. For this same age group, the BMI/Age curve was left-shifted (mean: -0.13; 1.12SD) with $3.4 \%$ (95\%CI $0.0-7.1$ ) of individuals presentlow BMI/Age and 2.6\% (95\%CI 0.0 - 5.9) present overweight or obesity, for both genders, respectively (Fig. 2).

Children and adolescents with HIV/ AIDS were generally positioned below the

Table 1 - Statistical summary measures for weight and height for children and adolescents with HIV/AIDS by age (years) bracket. Municipality of São Paulo, 2008 - 2009.

Tabela 1 - Medidas estatísticas resumo para peso e altura de crianças e adolescentes com HIV/aids por grupo etário. Município de São Paulo, 2008-2009.

\begin{tabular}{lccccc}
\hline \multirow{2}{*}{ Anthropometrical variables } & $\mathrm{n}$ & \multicolumn{2}{c}{ Weight $(\mathrm{kg})$} & \multicolumn{2}{c}{ Height (cm) } \\
\cline { 3 - 6 } & & Mean & SD & Mean & SD \\
\hline Children (total) & 71 & 22.3 & 7.5 & 116.1 & 18.3 \\
$<1$ & 4 & 9.3 & 0.9 & 70.1 & 4.8 \\
1 to 4 & 13 & 14.4 & 2.5 & 95.0 & 6.7 \\
5 to 9 & 54 & 25.1 & 6.0 & 124.6 & 9.6 \\
Adolescents (total) & 71 & 44.5 & 13.8 & 150.9 & 13.1 \\
10 to 14 & 54 & 40.7 & 12.1 & 147.0 & 11.6 \\
15 to 19 & 17 & 56.7 & 11.7 & 163.2 & 9.8 \\
\hline
\end{tabular}

SD: standard deviation.

SD: desvio padrão. 
NCHS reference curves ${ }^{20}$ and the Anjos ${ }^{21}$ study with the Brazilian population in weight and height for age (Fig. 3). In BMI/Age, different growth patterns were observed between genders: average values among boys were positioned, until seven years of age, above the reference curve, then from this age onward below the reference curve, while the pattern of growth among girls was the inverse, values being below the NCHS reference curve ${ }^{20}$ until four years of age, then above the curve after six (Fig. 3).

\section{0 to 4-year-old}

Weight to height

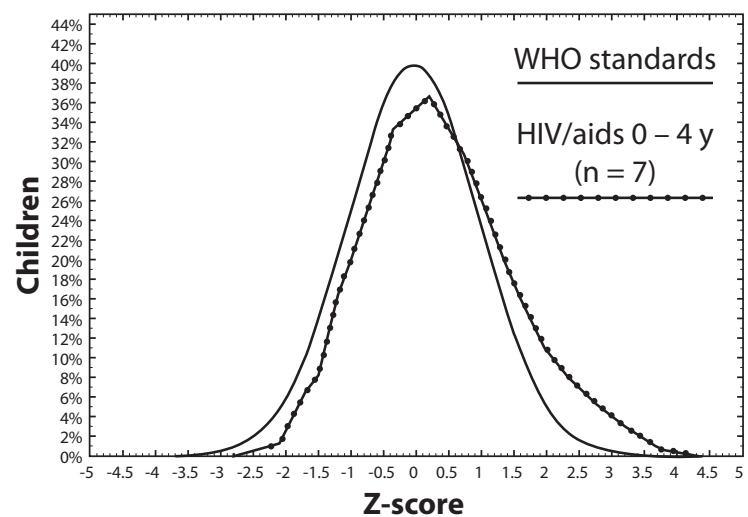

Height to age

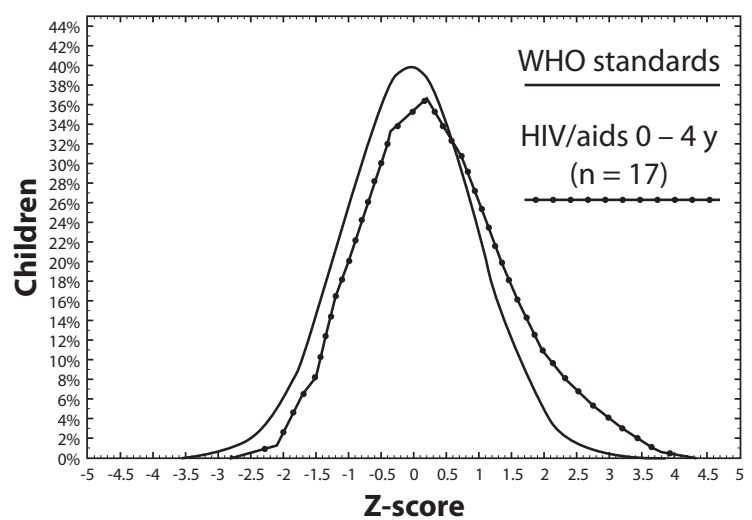

Figure 1 - Distribution of Z-score for weight for height and height for age in 0 to 4 years old children, from the population studied, with HIV/AIDS and the reference population ${ }^{19}$.

Figura 1 - Distribuição de escore Z para peso para estatura e estatura para idade, em crianças de 0 a 4 anos, da população estudada, com HIV/aids e da população de referência ${ }^{19}$.

\section{5 to 19 -year-old}

BMI to age

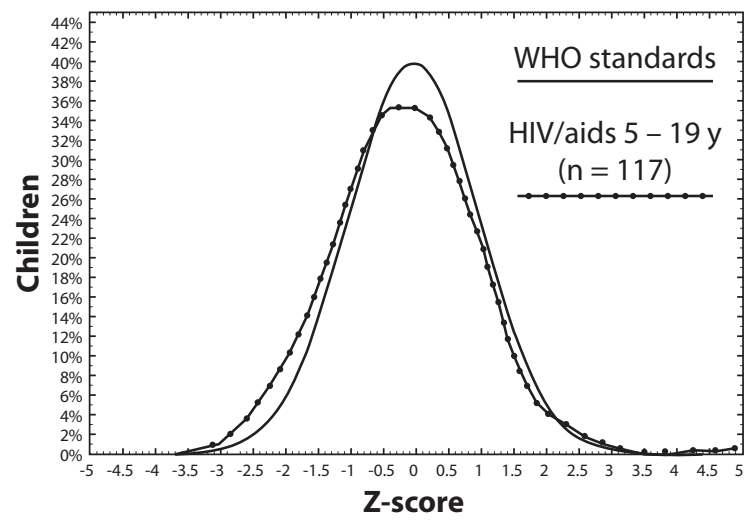

Height to age

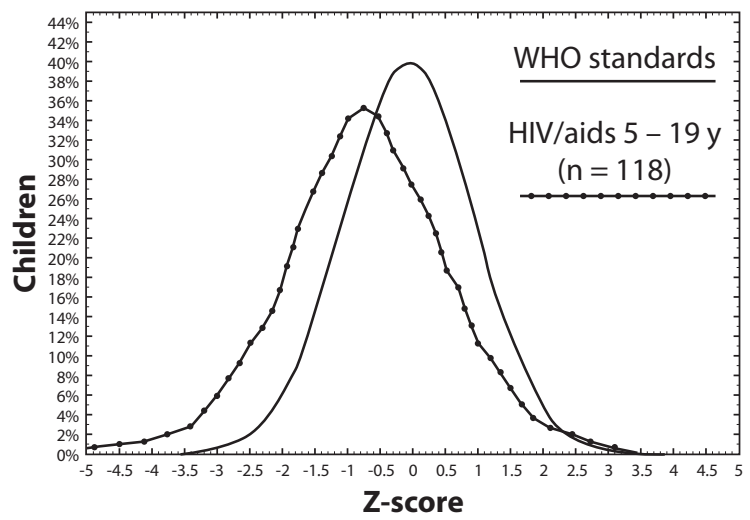

Figure 2 - Distribution of $Z$ score for body mass index for age and height for age in 5 to 19 years old children and adolescents from the population studied with HIV/AIDS and the reference population ${ }^{19}$.

Figura 2 - Distribuição de escore Z para índice de massa corporal para idade e estatura para idade em crianças e adolescentes de 5 a 19 anos da população estudada, com HIV/aids e a de referência ${ }^{19}$. 
Boys
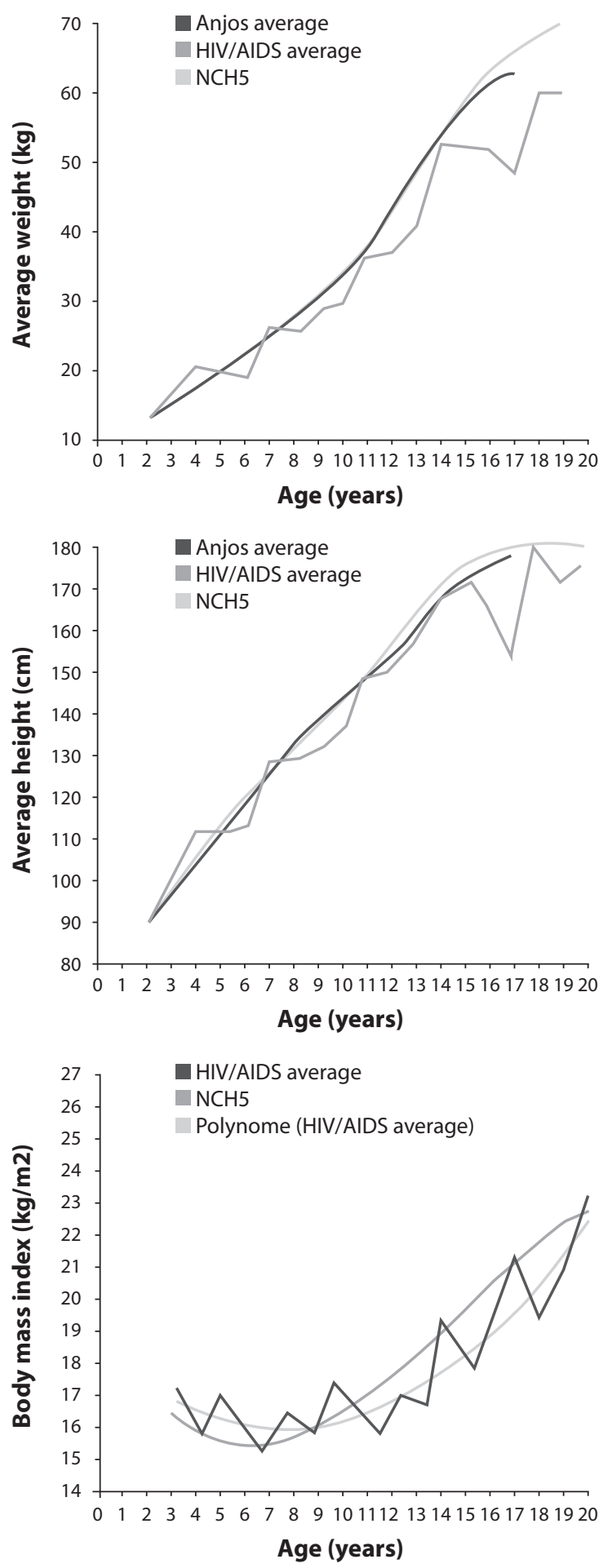

Girls
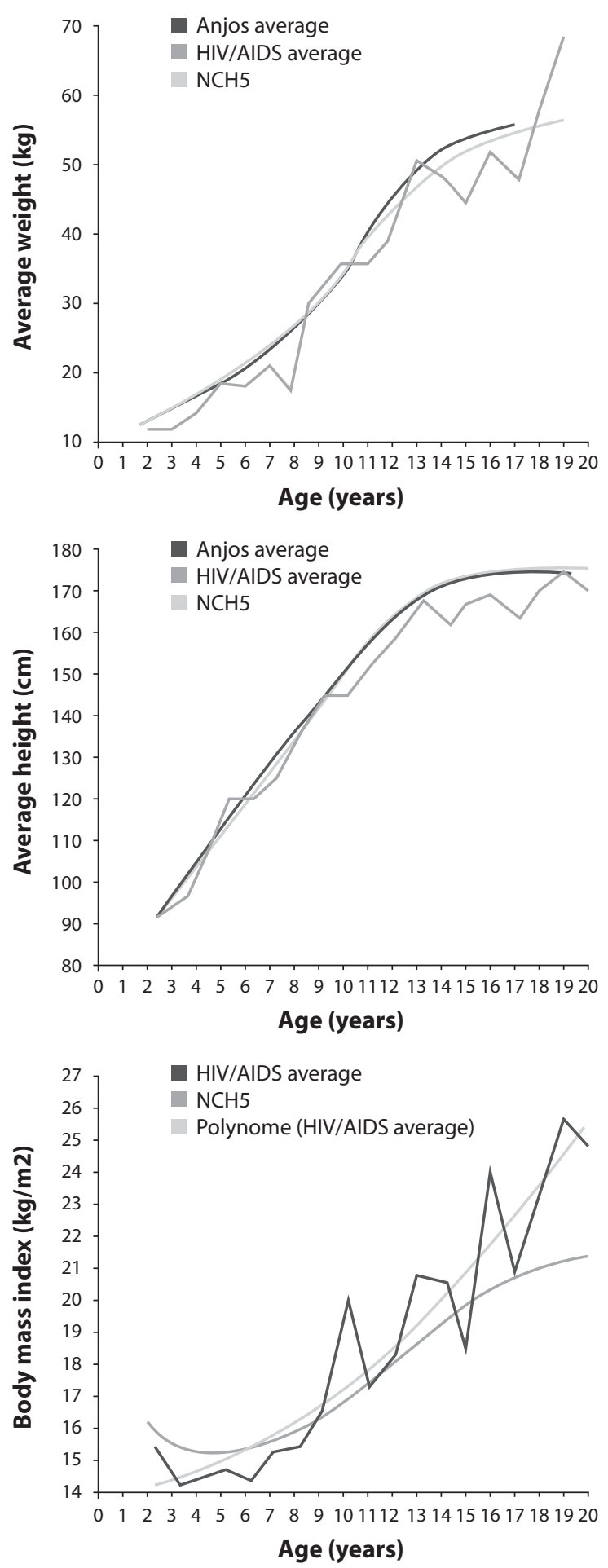

Figure 3 - Weight, height and average body mass index $\left(\mathrm{kg} / \mathrm{m}^{2}\right)$ for boys and girls with HIV/AIDS and for the reference population for the age bracket (years).

Figura 3 - Peso, estatura e índice de massa corporal médio $\left(\mathrm{kg} / \mathrm{m}^{2}\right)$ de meninos e meninas com HIV/aids e da população de referência por grupos etários (anos). 


\section{Adults and elderly}

In an exploratory approach, we can see that in adults and the elderly, coinfected people presented lower average weight (mean $=63.7 \mathrm{~kg}$ ) if compared to HIV infected people $(69.2 \mathrm{~kg})(\mathrm{p}=0.002$ for ANOVA and Scheffé) (data not presented). Figure 4 shows median weight $(\mathrm{kg})$ for adults and the elderly for both populations: (HIV/AIDS and the reference population ${ }^{22}$ ) for men (a) and women (b). Figure 4a shows that in men the median scores for weight for HIV/AIDS range from 65 to $70 \mathrm{~kg}$, while in the reference population the range is from 65 to $75 \mathrm{~kg}$; weight patterns are similar, with stability from 25 to 54 years of age, values being lower in the extreme age brackets. Figure $4 \mathrm{~b}$ shows that for women with HIV/AIDS the median weight seems to be lower as age increases, while in the reference population ${ }^{22}$ higher values are seen as age increases, except in the final age bracket.

\section{Discussion}

This study describes anthropometrical characteristics for PLWHA in different age brackets, assisted by SUS in São Paulo city. The strengths of this study are the wide age range of patients that are included in the analysis from infants to the elderly and the comparison between the anthropometrical characteristics of PLWHA and the general population. In the literature, the topic is commonly dealt with in terms of specific population groups, such as children alone or adults ${ }^{8,9,11}$.

Care for PLWHA and the availability of ARVT universally is in itself a structured activity in the SUS clinics and explains the high proportions of use found in this study, where, for adults, rates of the therapy use were similar to those found in the literature ${ }^{24}$. The fact that coinfection is greater among individuals not on ARVT is an important finding, and underscores the benefit of nutritional follow-up because, when there is coinfection, energy demand increases and the nutritional status may be impaired if demand is not met. The higher proportion of people not using ARVT among the coinfected people than notcoinfected ones may indicate low compliance with treatment for a range of reasons that lie beyond the scope of this study. Albuquerque et al. ${ }^{25}$, in a 2007 study of PLWHA in the city of Recife, in the state of Pernambuco, Brazil, also observed a statistically greater proportion of undernourished among HIV/AIDS patients coinfected with tuberculosis.
Male

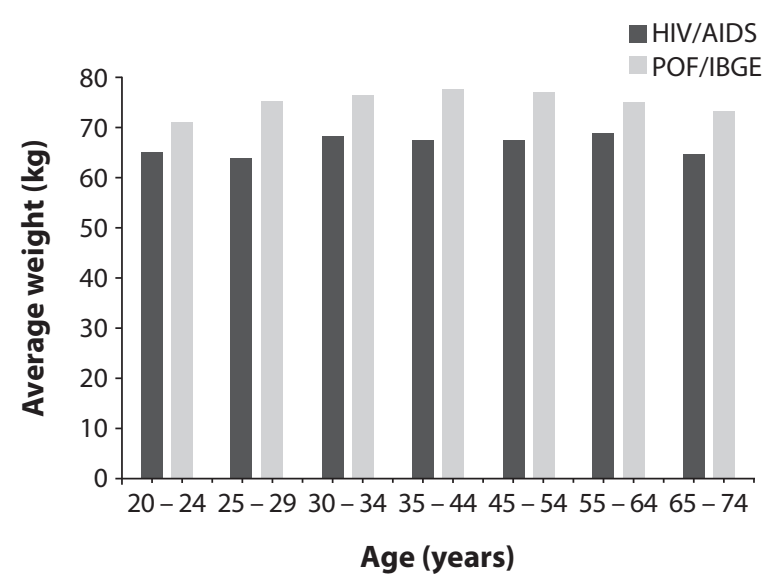

Female

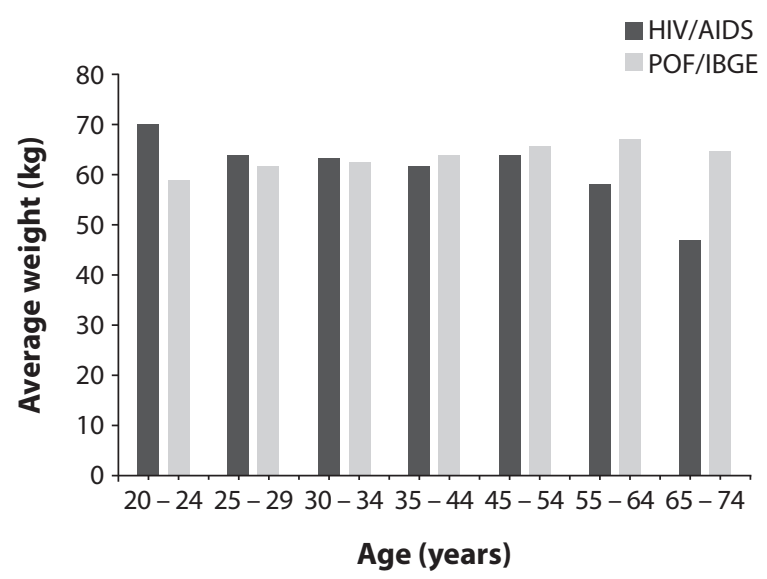

Figure 4 - Weight median for males (A) and females (B) with HIV/AIDS and for the reference population for the age groups (years).

Figura 4 - Mediana de peso para homens (A) e mulheres (B) com HIV/aids e para a população de referência por grupos etários (anos). 
The literature presents that food-medication interaction may occur, interfering with the effectiveness of treatment and contributing toward drug-resistance. The side-effects of ARVT use, such as dyslipidemia, and changes in glucose metabolism, among others, may be mitigated through follow-up and nutritional intervention ${ }^{4,6,7,9,10,12,13}$.

\section{Anthropometrical characteristics}

\section{Children and adolescents}

Growth among children and adolescents with HIV/AIDS in the present study was similar to patterns of growth in the general population, with an increase in weight and height with age ${ }^{26}$; however, these groups were generally below the reference curves ${ }^{20,21}$. This result is in accordance with the literature that shows the influence of ARVT on the bone mass depletion affecting, in its turn, both weight and height ${ }^{27}$.

For weight and height, and particularly for weight among boys, the difference between the curves might be marked with age possibly due to the negative influence on the bone mass growth that occurs during infancy and adolescence among PLWHA on treatment ${ }^{27}$. This pattern is shown from early ages for weight among girls. Understanding the possible influence of HIV/AIDS infection on children and adolescents growth and development is a challenge due to many variables involved in this phenomenon. Particularly in the case of children and adolescents with HIV/AIDS, the monitoring nutritional status is even more imperative, since the demands of growth and development compete with the need to fight off several opportunistic diseases. In addition to the clinical symptoms of side effects of ARVT use, such as nausea, vomiting, loss of appetite, and anemia, among others, which put this group at high nutritional risk ${ }^{13}$.

Evaluation of the nutritional status in adolescents is more complex than in children, owing to changesin body composition during this phase, such as increased fat deposits in girls due to the events of puberty, as well as chronological age. Criteria for anthropometrical evaluation in these groups are controversial, and although the need to incorporate maturational staging is recognized ${ }^{28}$, few meet it. This study also does not have this information, which may be considered a limitation. Curves based upon BMI/Age, despite providing practical solutions such as an epidemiological criterion for defining nutritional status, must be interpreted with care, because of changes in body composition resulting from biological maturing, which may become a complicating factor for this evaluation ${ }^{29}$.

Furthermore, it is important to point out that it would be appropriate to add other indicators of body composition for the assessment of the nutritional status of patients with HIV/AIDS, since BMI is not enough accurate, although literature indicates strong correlation with the total body fat ${ }^{8}$.

Owing to several methodological aspects, it is hard to compare data for nutritional status in children with HIV/AIDS and the uninfected population at large. A study by Souza ${ }^{30}$ with six years old children in the Brazilian state of Acre found a prevalence of low height for age of $2.8 \%$ in boys and $1.4 \%$ in girls. Anjos ${ }^{21}$ found similar results for 4 to 9 years old children living in the state of Rio de Janeiro (2.8 versus $1.9 \%$ ). The data for this study in the 0 to 5 years old bracket indicate a prevalence of $4.9 \%$ (95\%CI 1.8 - 10.3) for both sexes in terms of nutritional status. Victora et al. ${ }^{31}$, in a recent study, drew attention to a fall in the prevalence of height deficit in the last 30 years, possibly associated with increased access to health activities targeting mothers and children. Children with HIV/ AIDS can, therefore, be expected also to benefit from this scenario.

\section{o to 4 years old}

Given the 95\%CI for prevalence for high weight for height observed in the present study (5.9\%; 95\%CI 0 - 20), it seems similar to the findings of Anjos ${ }^{21}$ (6.3\% for girls and $7.7 \%$ for boys). On the other hand, in the study by Souza ${ }^{30}$, the prevalence for the category was $2 \%$ for both genders. Comparison of results for $\mathrm{H} / \mathrm{A}$ in children 
with HIV/AIDS are similar to those of the Anjos study ${ }^{21}$ with schoolchildren from the city of Rio de Janeiro, describing an H/A deficit in 4 to 9 years old. Although the results for both genders combined had not been presented by Anjos ${ }^{21}$, for purposes of comparison, a prevalence and $95 \% \mathrm{CI}$ for $\mathrm{Z}<-2$ was calculated, and a score of $2.3 \%$ (95\%CI $1.6-3.2)$ was obtained, while in the present study the values were $5.9 \%$ (95\%CI $0-20$ ), indicating similar results in these populations.

\section{5 to 19 years olds}

It is not clear if the BMI/A is an adequate index in HIV/AIDS populations. The result of overweight or obesity as of BMI/A [2.6\% (95\%CI $0-5.9)]$ for both genders together is lower than obtained by Sotelo ${ }^{32}$ in a population of school-age children in a central area of the city of São Paulo (22.2\%). This group presents lower weight as a possible result of the disease state, which includes symptoms, treatment and side effects ${ }^{12,13}$. It is important, however, to consider that the same BMI value, depending on gender and degree of maturation, may mean different things in terms of body composition and therefore nutritional risk, and should, as a result, be associated with other anthropometrical measurements ${ }^{29}$. For H/A, the observed shifting of the curve shows long-term involvement (stunting) seems important specially considering the prevalence of $11.9 \%$ of Z score under -2 SD.

\section{Adults and elderly}

Although the exploratory approach, it can be discussed that the lower average weight scores for adults and the elderly found in the present study were similar to those obtained by Diehl ${ }^{33}$ and Jaime ${ }^{34}$, both in populations of adults with HIV/AIDS, although they used CD4 values to categorize the infection situation. Whereas, in this study, men with HIV/AIDS showed lower weight in all age brackets than the population at large ${ }^{22}$, among women this was only observed for higher age brackets. These results need to be more studied in order to better understand the effect of HIV/AIDS related to gender and age. Oliveira et al. ${ }^{35}$ and Almeida et al. ${ }^{9}$ did not observe significant differences in the proportions of PLWHA in different BMI categories. However, in the study by Jaime et al. ${ }^{34}$, the average BMI was significantly lower among men than among women; however, no difference by sex was observed for average weight. Oliveira et al.$^{35}$, analyzing changes in weight, found that women presented a significantly greater change in this feature, both for gain and for loss, than men.

Among the elderly in particular, even among the healthy elderly, not only a physiological loss of bone and muscle mass that is observed. There are also functional changes, such as a reduction in basal metabolism, intestinal mobility, changes in digestion, difficulty in chewing and swallowing, changes in taste and less efficient absorption of nutrients, as well as other factors ${ }^{36}$ that may help explain the lower median weight scores than those for individuals of the same age in the population at large ${ }^{37}$.

\section{Conclusion}

The non-availability of data for weight change owing to the cross-sectional study design and the lack of data on subjects socio-economic background and clinical course, all limit more complete understanding, since they are aspects related to anthropometrical characteristics.

The presence of HIV/AIDS hinders understanding of the nutritional status in all the groups analyzed and shows the importance of further studies enabling patients to be followed throughout the process of infection and disease $\mathrm{e}^{4,6,8,10}$. The nutritional practice done as routine in the health services helps in the screening of cases to be prioritized for intervention purposes, in trend analyses and the guidance of clinical actions, assuring better results when adopted alongside other initiatives ${ }^{28}$. For children and adolescents with HIV/AIDS, the lower weight and height than in the non-infected population underscores the importance of using simple measurements, like weight and height, to monitor nutritional status and shows the need for 
further studies to investigate the difference in findings per gender. For adults and elderly, the worsening in the weight among the coinfected should be monitored. There is a need of reference populations curves from PLWHA for anthropometric characteristics and cut-off values for classifying people regarding their nutritional status.

\section{Acknowledgments}

The authors would like to thank the Programa Municipal de DST/AIDS for its support for the execution of the project and for the purchase of equipment for taking anthropometric measurements; the School of Public Health of the University of São Paulo for making available the space for training in anthropometric measurement; the health professionals working at the units where data was gathered (Bernadete de L. S. P. Fernandes, Célia M. S. Amorim,
Denise S. M. Oskata, Denise V. I. Momesso, Fátima S. Y. A. E. Sayed, Helga F. Piloto, Iraci C. Bonelli, Janete A. da Costa, Janice Chencinski, Maria Helena Vieira, Maria Iracema S. Heyn, Maria Regina Nagashima, Marisia Nagamini, Marta C. Pereira, Nivania F. Zauith, Valdeci D. R. Santos and Yara L. Macedo); Rubens Kon for helping to prepare the database for the analysis, and for his support in constructing the graphs and figures and formatting the final text. The authors participated in the following manner: KCB, the head researcher, carried out the project and coordinated the training in anthropometry and data-gathering, participated in the analysis and was responsible for drafting the article; DPB participated in carrying out the project, and took part in the analysis and drafting of the article; DESF ran the training and took part in drafting the article; VRSG and EATT took part in the training, gathered data, and participated in drafting the article.

\section{References}

1. São Paulo. Secretaria Municipal de Saúde. Boletim Epidemiológico de AIDS/DST e Hepatites B e C do Município de São Paulo. Ano XIII, n. 12, 2009. Available at http://www10.prefeitura.sp.gov.br/dstaids/novo_site/ images/fotos/Boletim2010.pdf (Accessed Jun 23, 20130).

2. Brasil. Ministério da Saúde. Boletim Epidemiológico AIDS/ DST. Ano VI, n. 1. Jan. a jun. 2009. Available at http:// www.aids.gov.br/sites/default/files/publicacao/2009/ boletim2009_final_pdf_24513.pdf(Accessed Jun 23, 2013).

3. Mahan L, Escott-Stump S. Krause alimentos, nutrição \& dietoterapia. 11 ed. São Paulo: Roca; 2005.

4. Polo Rodríguez R. Manual de nutrición y sida. 3 ed. Madrid: R. Polo; 2002.

5. Heath KV, Hogg RS, Singer J, O'Shaughnessy MV, Montaner JSG . Antiretroviral Treatment Patterns and Incident HIV-Associated Morphologic and Lipid Abnormalities in a Population-Based Cohort. JAIDS 2002; 30(4): 440-7.

6. Salomon JTPD, De Truchis P, Melchior JC. Nutrition and HIV infection. Br J Nutr 2002; 87 Suppl 1: S111-9.

7. Shevitz AH, Knox TA. Nutrition in the Era of Highly Active Antiretroviral Therapy. Clin Infect Dis 2001; 32(12): 1769-75.
8. Knox TA, Zafonte-Sanders M, Fields-Gardner C, Moen K Johansen D, Paton N. Assessment of Nutritional Status, Body Composition, and Human Immunodeficiency Virus-Associated Morphologic Changes. Clin Infect Dis 2003; 36 Suppl 2: S63-8.

9. Almeida L, Jaime P. Aspectos atuais sobre nutrição e Aids na era da terapia antiretroviral de alta atividade. J Bras Aids 2006; 7(1): 4-8.

10. Barbosa RMR, Fornés NS. Avaliação nutricional em pacientes infectados pelo Vírus da Imunodeficiência Adquirida. Rev Nutr Campinas 2003; 16(4): 461-70.

11. Sharpstone D, Murray C, Ross H, Phelan M, Crane R, Lepri AC, et al. The influence of nutritional and metabolic status on progression from asymptomatic HIV infection to AIDS-defining diagnosis. AIDS 1999; 13(10): 1221-6.

12. Food and Nutrition Technical Assistance (FANTA) Project. HIV/AIDS: A Guide For Nutritional Care and Support. 2 ed. Washington DC: Academy for Educational Development; 2004. Available at http://www.fantaproject.org/downloads/ pdfs/HIVAIDS_Guide02.pdf (Accessed Jun 23, 2013)

13. Fields-Gardner C, Fergusson P. Position of the American Dietetic Association and Dietitians of Canada: nutrition intervention in the care of persons with human immunodeficiency virus infection. J Am Diet Assoc 2004; 104(9): 1425-41. 
14. Lohman T, Roche AF, Martorell R. Anthropometric standardization reference manual. Champaign IL: Human Kinetics Books; 1988.

15. World Health Organization. Physical Status: the Use and Interpretation of Anthropometry - report of a WHO Expert Committee. Geneva; 1995. (WHO Technical Report Series, 854).

16. World Health Organization Multicentre Growth Reference Study Group. WHO Child Growth Standards based on length/ height, weight and age. Acta Paediatr Suppl 2006; 450: 76-85.

17. de Onis M, Onyango A, Borghi E, Siyam A, Nishida C, Siekmann J. Development of a WHO growth reference for school-aged children and adolescents. Bull World Health Organ. 2007; 85: 660-7.

18. World Health Organization. ANTHRO for personal computers, version 3.1, 2010: Software for assessing growth and development of the world's children. Geneve: WHO, 2010. Available at http://www.who.int/childgrowth/ software/en/ (Accessed Jun 23, 2013).

19. World Health Organization. ANTHROPLUS for personal computers. Manual: Software for assessing growth of the world's children and adolescents. Geneva: WHO, 2009. Available at http://www.who.int/growthref/tools/en/ (Accessed Jun 23, 2013).

20. Kuczmarski RJ, Ogden CL, Guo SS, Grummer-Strawn LM, Flegal KM, Mei Z, et al. 2000 CDC Growth Charts for the United States: methods and development. National Center for Health Statistics. Vital Health Stat 11 2002; 246: 1-190.

21. Anjos LA, Castro IRR, Engstrom EM, Azevedo AMA. Crescimento e estado nutricional em amostra probabilística de escolares no Município do Rio de Janeiro, 1999. Cad Saúde Pública 2003; 19 Suppl 1: S171-9.

22. Instituto Brasileiro de Geografia e Estatística. Pesquisa de Orçamentos Familiares 2008-2009: antropometria e estado nutricional de crianças, adolescentes e adultos no Brasil. Rio de Janeiro: IBGE; 2010.

23. Stata Corporation. Stata Statistical software for professional. [computer program] Version 11. Texas: College Statio; 2009.

24. Barreto ML, Teixeira MG, Bastos FI, Ximenes RA, Barata $\mathrm{RB}$, Rodrigues LC. Successes and failures in the control of infectious diseases in Brazil: social and environmental context, policies, interventions, and research needs. Lancet 2011; 377: 1877-89.

25. Albuquerque MDM, Ximenes RAA, Maruza M, Batista J d'Arc L, Albuquerque MFPMA. Índice de massa corporal em pacientes co-infectados pela tuberculose-HIV em hospital de referência da cidade de Recife, Estado Pernambuco, Brasil. Epidemiol Serv Saúde 2009; 18(2): 153-60.

26. Tanner JM. Growth at adolescence: With a general consideration of the effects of hereditary and environmental factors upon growth and maturation from birth to maturity. 2 ed. Oxford: Blackweell Scientific Publications; 1962. 325 p.
27. Lima LRA, Silva RCR, Giuliano ICB, Sakunod T, Brincase SM, Carvalho AP. Bone mass in children and adolescents infected with human immunodeficiency virus. J Pediatr (Rio J) 2013; 89(1): 91-9.

28. Anjos LA dos, Veiga GV da, Castro IRR de. Distribuição dos valores do índice de massa corporal da população brasileira até 25 anos. Rev Panam Salud Publica 1998; 3(3): 164-73.

29. Conde $\mathrm{WL}$, Monteiro CA. Body mass index cutoff points for evaluation of nutritional status in Brazilian children and adolescents. J Pediatr (Rio J) 2006; 82(4): 266-72.

30. Souza OF, Cruz MDS. Estado nutricional de escolares no ensino infantil de Rio Branco/AC. Rev Bras Cineantropom Desempenho Hum 2006; 8(2): 39-44.

31. Victora CG, Aquino EML, do Carmo Leal M, Monteiro CA, Barros FC, Szwarcwald CL. Maternal and child health in Brazil: progress and challenges. Lancet 2011; 377(9780): 1863-76.

32. Sotelo Y de OM, Colugnati FAB, Taddei JA de AC. Prevalência de sobrepeso e obesidade entre escolares da rede pública segundo três critérios de diagnóstico antropométrico. Cad Saúde Pública 2004; 20(1): 233-40.

33. Diehl LA, Dias JR, Paes ACS, Thomazini MC, Garcia LR, Cinagawa E, et al. Prevalência da lipodistrofia associada ao HIV em pacientes ambulatoriais brasileiros: relação com síndrome metabólica e fatores de risco cardiovascular. Arq Bras Endocrinol Metab 2008; 52(4): 658-67.

34. Jaime PC, Florindo AA, Latorre M do RD de O, Brasil BG, Santos ECM dos, Segurado AAC. Prevalência de sobrepeso e obesidade abdominal em indivíduos portadores de HIV/ AIDS, em uso de terapia anti-retroviral de alta potência. Rev Bras Epidemiol 2004; 7(1): 65-72.

35. Oliveira OMV, Medeiros RS, Nascimento MAB do, De Boni MS. Perfil nutricional e fatores de risco para obesidade central de pessoas que vivem com HIV/AIDS. Comun Ciênc Saúde 2008; 19(4): 305-14.

36. Najas MS, Sachs A. Avaliação nutricional do idoso. In: Papaléo Netto, M. Gerontologia.São Paulo: Atheneu; 1996. p.242-7.

37. São Paulo (SP). Secretaria Municipal da Saúde. Coordenação de Epidemiologia e Informação - CEInfo. Boletim ISA - Capital 2008, n. 2, 2010: Estado nutricional, insatisfação em relação ao peso atual e comportamento relacionado ao desejo de emagrecer na cidade de São Paulo. São Paulo: CEInfo; 2010. 40 p. Available at http:// www.prefeitura.sp.gov.br/cidade/secretarias/upload/ saude/arquivos/publicacoes/EstadoNutricional.pdf (Accessed June 23, 2013). 